\title{
The Role of Partnership Public and Private Sectors in the Pursuit of Excellence for Marketing Communications Services Jordanian (Case Study)
}

\author{
Ali Falah Al-zoubi ${ }^{1}$ \\ ${ }^{1}$ Marketing Department, Zarqaa University, Jordan \\ Correspondence: Ali Falah Al-zoubi, Associate professor of marketing, Faculty of Economic and Administrative \\ Science, Zarqaa University, P. O. Box 132222, Zarqa 13132, Jordan. E-mail: alzoubifali@yahoo.com
}

Received: September 13, 2013 Accepted: October 8, $2013 \quad$ Online Published: January 22, 2014

doi:10.5539/ijms.v6n1p127 URL: http://dx.doi.org/10.5539/ijms.v6n1p127

\begin{abstract}
This study aimed to clarify the role of partnership public and private sectors in achieving excellence catalog for telecommunications services Jordanian through the efficiency\& quality and Developed existing services and introduce new services to existing customers and prospective down to their satisfaction. That this partnership came after the enactment of privatization in Jordan in 1999, to care for owners interest of customers and suppliers, employees and owners of Wallace And suppliers, shareholders and society as a whole, has been a community study is Jordan Telecom and the study sample is systematic random sample included (40) customers from the permanent and the type of study is a case of either study tool was questionnaire. Has circuit problem of the study on that there is a lack in the role of partnership public and private sectors to achieve excellence catalog for telecommunications services, despite the availability and resources and the potential.

And the importance of this study focus on this point which is: Partnerships between private and public sectors makes providing services processes more efficient. The redistribution of roles between the public sector and the private sector and the gradual withdrawal of the state from certain economic activities and make way for private initiatives by encouraging private investment. The study was built on two main hypotheses:
\end{abstract}

-First major premise: there are no statistically significant relationship between the role of the partnership public and private sectors and excellence and efficiency of marketing communications services and quality of Jordan.

-Second major premise: there are no statistically significant relationship between the role of the partnership public and private sectors and provide vital communication services and in an excellent manner and customer satisfaction.

The study found several findings and recommendations of the most important:

1) The necessity of training for the employees to learn them that the citizen is the actual capital for the service sector in any business.

2) The organization has to update its services to be more fit with technological development.

3) The competition in the service sector requires a new culture that makes employees sense the customer needs.

Keywords: partnership, public and private sector, achieving marketing excellence, services, privatization

\section{Introduction}

Study addresses the subject of partnership between the public and private sectors where privatization is as contemporary means in the context of public sector reform and restructuring in developing countries in general and in Jordan in particular after the shifting role of the state to development and corrective action. (Hamed Badr, 2010, p. 61)

The partnership approach this fall and in a clear and comprehensive economic reform policies recommended by the World Bank and of Jordan and consider the issue of restructuring and a country's correction driven by the IMF and the World Bank in extremely complex.

The policies of privatization are: 
- Privatization Automatic: summed up in encouraging the private sector (individuals and institutions) and support a position to increase its weight in the national economy, that does not affect this process in a position that the activities undertaken by the public sector, and adopt this method is mainly on the implementation of state of the means of motivational encourages the private sector, with creating appropriate economic base for the growth of this sector, with the launch of market forces and the provision of appropriate means for investment and production in the various institutions.

- Structural privatization: is to reduce the role of the public sector through the sale of some of its production and service institutions or transfer management to the private sector, and thus falls this method clearly and comprehensively in the economic reform policies recommended by the World Bank and implemented by Jordan. The work done by the British Labour government of transformation of public sector institutions (whether by sale or lease) to the private sector of the leading international experiences in structural privatization method. (John Graham \& Roy Herberger, 2003, pp. 160-8).

Recently organizations either public or private have affected by unlimited change in their customers needs and behavior operations, activities, and beneficiaries diversity, who are stockholders, consumer group, and the whole community.

Organization have faced turbulent environment through many factors such as the diversity of customer needs, high level of competition, pressure from regulators and consumer groups, and the technological, informational, communicational changes.

Those forces affected organizations in many areas, for example to expand their operations and activities, to enter new markets, in making strategies for long term objectives. These forces and their results lead organizations to affiliate ways, manners, strategies, polices to change themselves to be excellent organizations.

It is more critical to view organizations excellence as a steady issue because excellence may be viewed according to several perspectives: Stake holders, employees, customers, and other parties.

However, partnerships between public and private sectors is one way to achieve organizational excellence. These partnerships may be performed through the following techniques:

- Facilitating capital sales

- Sales to strategic investors

- Concession agreements

- Management contracts

- Franchising and other methods

The term used to express those techniques is privatization, but we have to distinguish the full privatization and partial privatization.

This paper will strongly focus on the role of partial privatization (partnership between the two sectors) in achieving excellence in providing services.

\section{The Study Importance}

It is typically much more difficult for the public sector to provide services than for the private sector. The public sector who represents the government is the hub of many process: it regulates land use and citizen behavior, it runs businesses such as housing companies and power companies, it is a political organization managing public debates, it runs defense requirements, also it is an important player in local culture by sponsoring or owning cultural arenas like municipal libraries and museums, and many other issues. Managing and providing services to many users, customers, citizens may need a high cost, and because the private sector works more closely to the market fluctuations, this makes the private sector more effective in controlling these costs. And the importance of this study focus on this points which is:

- The redistribution of roles between the public sector and the private sector and the gradual withdrawal of the state from certain economic activities and make way for private initiatives by encouraging private investment.

- $\quad$ Partnership between private and public sectors makes providing services processes more efficient.

- Alleviate the financial burden borne by the general budget as a result of its support for the loss-making public enterprises and attention to infrastructure and economic establishments of strategic importance. 
- Work to increase competition by encouraging the private sector to enter the fields of economic monopoly of the public sector.

- The importance of partnership between the public and private sectors in order to stimulate the Jordanian national economy and enhancing its competitiveness.

\section{The Study Objectives}

The main objectives of this study are:

- To describe the expected role of the private sector as a result of the partnership between private sector and public sector.

- To highlight the benefits of this partnership for the two sectors through the case of Jordan telecom.

- Work on the development and revitalization of the financial market.

- Work to create the right investment climate and encourage them to attract capital local, Arab and foreign.

- Work to achieve the objectives of efficiency, development and launch of dynamic growth in the economy and job creation.

- The development of administrative and managerial competencies and marketing.

\section{The Study Problem and Questions}

The proportion of (PPP) is $51 \%$ of the public sector and $49 \%$ for the private sector and distributes capital this society and by $100 \%$ to a number of shares distributed at what the owners and the customers and employees and interested members of the community with determining the upper limit for the purchase of shares and per capita.

The study problem can be presented with the issue of whether:

"Partnerships between public sector and private sector enable private sector to participate in the development process in a country"

More over this study presents the following questions:

Q1. What is the Partnership form that makes it more effective in providing public services?

Q2. What are the differences in the services provided by Jordan telecom before and after the privatization process?

Q3. How customer satisfaction with the quality of telecommunications services?

Q4. What customer satisfaction with service delivery methods?

\section{The Study Hypotheses}

According to the questions stated later, this study intended to examine the following Hypotheses:

1) First major premise: there are no statistically significant relationship between the role of the partnership public and private sectors and excellence and efficiency of marketing communications services and quality of Jordan.

2) Second major premise: there are no statistically significant relationship between the role of the partnership public and private sectors and provide vital communication services and in an excellent manner and customer satisfaction.

\section{The Study Model}

\begin{tabular}{|l|}
\hline Independent Variables \\
\hline - $\quad$ Partnerships between the public \\
and private sectors: \\
- $\quad$ National economy \\
- $\quad$ Enhancing competitiveness \\
\\
\end{tabular}

\begin{tabular}{|ll|}
\hline \multicolumn{1}{|l}{ Dependent Variables } \\
\hline- & Efficiency in providing services \\
- & Providing vital services in excellent way \\
- & Customer satisfaction \\
- & Quality services \\
- & Excellent manner. \\
\hline & Right investment \\
\hline
\end{tabular}




\section{Theoretical Procedural Definition of the Study Variables}

* Public sectors: public often means official, or a legal corporation (governmental) providing services to the public.

* Private sector: companies or individual businesses that is not a member of the government.

* Partnerships between the public and private sectors: This variable may takes different definitions that depends on the objectives of such partnerships, it may means the transfer of public assets to the private sector, by sale, or contracting out, or transfer of government services or assets to the private sector (Ernst, Young and others, 2005).

* Efficiency in providing services: This variable includes communication between the services provider and the citizen by focusing on service design, service delivery, and service use and responses to services.

* Adoption of new technologies: Because of the diversity of technology devices, the organization has to answer several questions to specify its option in selection the appropriate technique used to deliver services, such as; what is the proper design of electronic services? What makes people use them and how are they used now? How should users' requirements and wishes best be met? And how can governments use these new ways of organizing the information, services, communication flow between their departments and their inhabitants (Gronlund, 2000, p.xx).

* Vital services: include water, education, health, telephones, and many others.

* Privatization: mean in a general sense the transition from dependence on the public sector to the private sector, whether the ownership or management. And giving an active role for the private sector in the economic life of the community.

\section{Methodology}

\subsection{Type of Study}

This study is a descriptive quantitative one in order to highlight the differences in providing services in Jordan Telecommunication company and to measure the degree of excellence in providing Telecommunication services through comparing the organizations situation before and after the participation of the private sector in its management.

\subsection{Study Population and Sample}

The study population is Jordan Telecom as a case study, and the sample for measuring the excellence of providing Telecommunication services counted (60) citizens. The study sample was kind is systematic random sample.

\subsection{Study Instruments}

-The Secondary data: was collected from the books, researches and surveys, either published in the libraries or on the internet.

-The primary data: was collected through a questionnaire, for the users of the Telecommunication services, (Karmush, 2007), Questionnaire was distributed (40) has been restored (37) questionnaire and by 93\%, which is sufficient for analysis.

\section{Previous Studies}

Al-zoubi ali (2011): "Public sectors partnership". The essay compares between the traditional process in partnership between the tow sectors; private and public, and the new partnership style between them. The traditional partnership based on the acceptance of the government to provide the land, the needed facilities, and the investment risk coverage. While the private investor will provide the capital and management during an agreed period. The new partnership between the public and private sectors, promoted and supervised by the Privatization Executive Board, where the private sector would provide what the government lacks, funds and efficient management, while the government keeps the ownership rights and receives a share of revenues.

Jawad Al-Hadid (2008): "Jc Bank sponsors the partnership forum between the private and public sectors". Through his talk to the forum Dr. Al-Hadid considered the partnership between the tow sectors as a comprehensive strategy, he said "The economic development in the Arab region imposes on the respective governments to adopt such strategies, to give the private sector the opportunity to play an active role in the development process. One of the significant outcomes of partnerships between the tow sector is to find deeprooted solutions to the economic and social problems the Arab World is facing nowadays. 
Cecilia, Torta, Jada (2002): Workshop on public-private partnership in the Water Sector: The case of the Middle East and North Africa Region". Cairo, Egypt. The study aimed on pointed out the benefits of the participant of the private sector in managing the water sector. The author suggested a potential solution which is the increasing involvement of the private sector to provide water services for domestic, industrial and agricultural uses and to generate hydroelectric power. Then the author added that the private sector can play the following roles: "Improving very substantially the existing technical and financial management of urban water and waste water sector. Attracting new investments for the water sector as a whole, which public sector is no longer in a position to supply fully in a timely manner."

Smith (2008): "Government-Private Sector Partnerships as a catalyst for Economic Growth and Development. The study aimed to illustrate some of the partnerships between the public and private sectors procedures and techniques performed by many commonwealth countries. The author indicated that "many commonwealth countries have reduced the role of the public sector in the economy and have been activity engaged in encouraging the growth of the private sector". The most important factor in successful partnership between the public and private sector is creation of enabling environment, and this requires training programs for the public sector executives to broaden their understanding of the range of the partnership options that exists- as smith- " in emerging markets and to enhance capacity to manage partner ships.

Albert P. C. Chan; Patrick T. I. Lam; Daniel W. M. Chan, M.ASCE; Esther Cheung; and Yongjian Ke (2009): Comparison between China and Hong Kong Special Administrative Region.The private sector has long been involved in delivering public sector projects, whether its role has been as a partner or just as a contractor for the government. Over recent years the interest in adopting public private partnerships PPPs has increased internationally. Many research studies have presented positive reasons for the governments and the private sector to welcome this form of procurement, rather than continue adopting the traditional options. This paper aims to explore and compare the key drivers for adopting PPP in China and the Hong Kong Special Administrative Region referred to as Hong Kong from here onwards. An empirical questionnaire survey was conducted in both of these administrative systems and survey respondents were invited to rate their perceptions on the importance of 15 different drivers identified. Eighty-seven completed survey questionnaires were returned for analysis. The findings indicated that respondents from China rated economy-related drivers higher, whereas Hong Kong respondents tended to rate efficiency-related drivers higher. China's demand for more public infrastructure and services has imposed great pressure on the government's budget, and therefore economic drivers were rated higher. On the other hand, with adequate financial reserve in hand and budget surplus over recent years, Hong Kong has tended to prefer paying for projects upfront, and hence efficiency was regarded more significantly. Among the 15 drivers, both of the respondents from China and Hong Kong selected, "provide an integrated solution for public infrastructure/services" and "solve the problem of public sector budget restraint" to be within the top three drivers. Despite the general agreement on the ranking pattern, the results of independent two-sample t-test showed that China and Hong Kong shared very different views on the driver "reduce the total project cost." This driver was ranked rather high by the mainland Chinese respondents, but much lower by the Hong Kong respondents. This finding can be construed that economic drivers are in general rated higher in China as compared to that in Hong Kong.

Monica Bedi (2010): An integrated frame work for service quality, customer satisfaction and behavioral responses in Indian banking industry - A comparison of public and private sector banks: This study attempts to investigate the relationship between service quality, over all customer satisfaction and behavioral intentions across public and private banks in India. The findings indicated that service quality is a significant determinant of customer satisfaction in Indian banking industry irrespective of public and private sector banks. However, different dimensions of service quality were found to be statistically significant across public and private banks. Customer satisfaction was found to be strongly associated with propensity to recommend. The study will help banks to redefine their corporate image to one that is customer-focused and driven by service quality.

Süleyman Yaman Koçak (2011): The Comparison between Hungary and Turkey: Regional Development Agencies Turkey. In this paper, Hungary and Turkey will be compared according to their Regional Development Agency practices. Hungary is chosen as a comparison country with Turkey because they are similar in many respects. Both countries have an understanding of regional policy of their own even before the candidacy decision, a centralised administrative structure, having deep historical legacy as an ex-parts of Austria- Hungary and Ottoman Empires, and It must be noted that the requirements of the EU for adopting the acquis in the field of administrative policy and its proper implementation have an institutional impact on local development and local governance. In this context, the European Commission systematically adapted their regional development strategy to the regulations with the pre-accession funds and challenged their centralized state system. Therefore, 
Hungary is a good example for comparison with Turkey regarding territorial restructuring, institution building, the evaluation of the roles of actors participating in the regional development agencies and the factors affecting the functioning of the these agencies.

Hassan Mobeen Alam, Ali Raza, Muhammad Akram (2011): A Financial Performance Comparison of Public Vs Private Banks: The Case of Commercial Banking Sector of Pakistan, Commercial banks are major component of financial sector and take part in the growth of economy. To compare the financial performance of public banks and private banks which were working in Pakistan during the period of 2006-2009 is intend of this study. Bank size and financial ratios are taken as variables such as p 56 efficiency / profitability ratios, capital / leverage ratios, liquidity ratios and asset quality ratios. Study concludes that ranking of banks differ as the financial ratio changes and intend of this study is fully academic. Extension in the period of analysis may tend to further study. Conclusions On the basis of results and analysis, public and private banks has different ranking based on bank size and each financial ratio categories such as efficiency / profitability ratios, capital / leverage ratio, liquidity ratios, and asset quality ratios.

a. Based on bank size, private banks are at first, and public banks are second.

b. Based on efficiency / profitability ratios, public banks are at first on the base of return on total assets (ROA) and return on owners' equity (ROE). Whereas, private banks are at first on the base of spread ratio, non-interest expenses to total income ratio and net interest margin ratio.

c. Based on liquidity ratios, public banks are at first on the base of cash \& cash equivalents to total assets ratio of bank and investments to total assets ratio. Whereas private banks are at first on the base of advances to total assets ratio and debt to assets ratio.

d. Based on capital / leverage ratios, public banks are at first on the base of break up value per share and deposits to equity ratio. Whereas private banks are at first on the base of capital ratio.

Imamul Haque (2011): Service Quality in Retail Banking- A Comparative Study between Public Sector Banks \& Private Sector Banks. Service quality in Indian Banking Sector is considered as main determinant of customer satisfaction. Before liberalization the banking sector in India was mainly dominated by nationalized banks. In the pre-liberalized era, the nationalized banks did not pay much attention on the service quality performance and customer satisfaction. After liberalization and implementation of the Narsimham Committee Report, Indian Banks are facing tough competition from the new private and foreign banks observing International Banking Standard. These new generation banks were characterized by the usage of modern information technology network and modern banking services, like ATM, debit card, online banking facilities. Customers have a wide ranging banking services offered and delivered by modern private sector banks and foreign banks. The need of hour for the Indian banking sector is to enhance their services quality and shore up their competitive capabilities, making the banks more market oriented and customer friendly. This present study is an attempt to focus on the service quality in Retail Banking and highlight the dimensions of quality banking service in the private sector banks and public sector banks. But the Conclusion This paper attempted to measure and compare the level of service quality received by retail bank customers in private and public sector banks. It also identified the dimensions of the service quality in public sector banks and private sector banks by testing SERVQUAL instrument. SERVQUAL was found to be a valid measure of service quality in both bank sectors. The study suggests that customers' perception regarding the service quality dimension in both the banks vary. service quality scores of public banks and private bankspublic bank.

Ce'line Desmarais and Emmanuel Abord de (2010): Are there still differences between the roles of private and public sector managers? In France, the differences between public and private organizations seem to have been reduced by the ubiquity of some management tools and approaches, and, at the same time, highlighted by the political environment,stereo types, and negative perceptions of French public management. Given this confusion, systematic empirical studies are needed to determine the degree of convergence, if any, between management in the public and private sectors. The present study analyzed a survey of 908 managers, in order to determine whether differences in managerial practices still exist. Our results show that some differences do persist, although they are relatively small.

\section{Theoretical Background}

Because today's world is the world, the service organizations including telecommunications organizations seeking as part of the services industry to keep up with all directions and new variables, especially after he became customers looking for quality, speed and cost became Jordan Telecom binding searching for excellence in providing services and this does not only come through adoption of service-marketing strategies with special 
features designed to value and improve performance (ali alzoubi, 2010, p8).

The pros this partnership PPP quality and speed with lower cost to complete projects, and the division of risk between the two sectors, as private or public sector does not bear the risk alone, and the partnership will lead to increased efficiency and accuracy of designs and the implementation of infrastructure projects, not only that, but to ensure financing, operation and maintenance and development of these projects, including return on citizen access to quality services and keeping the property and assets of the nation and the financial return worthwhile investor. One of the best advantages of this partnership PPP risk allocation, and quality in the management of public money, transparency, and through this project we can open market new investment, and be new outlet for investment development instead of real estate investment, and add to the stock market, characterized by investment funds in infrastructure projects and partnership the public and private sectors sustainable and stable growth, which gives added value to the project awaited partnership between the public and private sectors (Arab newspaper, 05.17.2012).

Partnerships between the public and private sector is not an ordinary procedure, in many cases around the world, privatization either full or partial is more likely to be a part of over all economic package. For Jordan, the process wasn't a mere economic luxury, a fad or simulation of other countries experiences, but it was dictated and imposed on the kingdom as a result of various surveys and studies of public- sector projects. These studies focused on the poorness in the public sector organizations in efficiency, and management, and employment policies, squander of public funds, administrative archaism, substandard services, and high indebtedness, while the private sector organizations were accomplishing higher returns and financial results, beside creating new job opportunities, with a high level of efficiency in the administrative and employment policies (www.google.com/privatization/briefs profiling country).

Further more, globalization and its effects require new scenarios for the rapidly changes in the businesses world, this mainly needs, administrative improvement, increasing the ability of the administrative approaches to adapt and respond for the openness policy (Sushil, 2000, p.2), these changes and the new environment obliged many countries and many businesses to tend toward market economy rather than command economy, market economy requires from the private sector to own and manage the resources (Robbins \& coulter, 2005, p.87), and to reduce the innovations gap between the private and public sectors (Hisrich \& Peter, 2002, p.17).

Excellence in providing services means that the user want the service in a certain time, characterized according to his perspective to satisfy his needs and wishes. In this area the partnership between the public and private sector can overcome this problem. In India for example the ministry of Defense is a major purchaser of quality products according to laboratories norms and standards. A very common complaint is that the time requirement at government laboratories and test houses is uniformly high and the long waiting periods create problems for organizations who produce this facilities. This has forced them to take advantage of the private test houses, though they have to pay a higher price.

It has to be conceded that government test houses have some of the best facilities and they have to operate under pressure. This pressure generated tow alternatives: to compete on par with the private sector, or to participate with the private sector to cut down the waiting time (Gopalatirishnam, 2006).

Here we can say that collaboration between the public and private sector contributed in development through promoting excellence in providing services, and to change expertise and experiences between the tow sectors. (Nuaim, 2008).

In Jordan there are many governmental projects have turned to managed by the private sector, either through partnerships or by privatization processes. Jordan telecommunications, Water Authority, Royal Jordanian Airlines, Jordan Cement company and other, are examples for the Jordanian Government tendency toward providing the opportunity to the private sector to play its role in the economic development.

Partnerships between the two sectors allows to exchange expertise, experiences, skills and knowledge in order to create a new supporter environment that aims to provide excellent services for the community, especially the vital services.

This excellence derived from the fact of, tow opinions are better than one, accumulated experience is better than single experience and so on.

From here we can say that partnership between the two sectors is not the ultimate goal, but it is a device to achieve the objectives of comprehensive development through the following: 
1) Performance standards should aim to improve efficiency and quality decrease cost, and increase productivity by out sourcing to the private sector the operation of projects and management of processes, because it has the rich experiences and excellence at such fields.

2) Attract capitals, encourage investment, practice transparency and openness.

3) Eliminate the decline in central government support for services, public utilities, municipalities, and projects.

4) Eliminate the government and the public sector from the burdens of funding and managing of loosing projects.

5) Adaptation with the global trend of competition, open markets, and globalization.

6) Control the projects by using recent flexible methods that depend on advanced technology, to enable competitiveness at global market, and train and recruit the citizens (Nuaim, 2008).

Moreover, partnerships between the public and private sectors require more public sector involvement, rather than necessarily less.

To achieve the desired development results requires commitment, understanding and trust on both sides. Time, effort and resources must be invested in managing partnerships successfully.

In this way partnerships between the public and private sectors can make a significant contribution to economic growth and development, in areas such as creating and improving the potential infrastructure, access to public services and improving social services. Also, PPPs play an important role in delivering modernized public services, in asset creation and in fostering economic development.

Providing modern service in modern ways makes the citizen in any country happy, and increase the degree of his loyalty to his country (Tanuwidjaja, 2006).

The decrease in the efficiency of the public sector companies or failure to a number of reasons, often are these economic units on the basis of non-economic as mostly the considerations social, political and ideological and sells its products at prices below cost price and is the second reason that the operations of public enterprises, can besource and drain easy for the public treasury (Xie, B., W. N. Davidson III, \& P. J. DaDalt, 2003, pp. 295-316) .

In Jordan begin implementing privatization within the economic reform program since the end of 1994 . Through decisions and finally package Law No. (45) of 1999 on the privatization.

In 1995, the Jordanian Government carried out the idea of restructure the telecom sector. One of the government options was privatization the sector.

Telecom corporation was a government entity which suffered from constrained freedom in planning and limited funding.

The objectives of privatization were:

- Raise revenues to the Treasury.

- Increase efficiency of state- owned projects.

- Expand investment by private sector financing.

- Increase network and improve service.

- Develop Jordan into a regional hub for telecom services.

- Transfer technology and management expertise.

- Increase private investments in Jordan Telecom.

- Increase government revenues through proceeds and higher future taxes.

If we recall the definition of excellent organization which taking care of all stakeholders namely: Customer, employees, suppliers, share holders, and society as a whole (AL-Damen, 2006, pp. 19-20), we can find that Jordan Telecom has achieved excellence in many areas including excellent services, through improving human resources and developing the current Telecommunication services and providing new Telecommunication services.

These services include:

- Mobile cellular service.

- Internet access service. 
- $\quad$ Prepaid calling service.

The new services provided by Jordan Telecom are:

- Mobile GSM.

- ISDN Primary Rate Access.

- $\quad$ Portal; Jordan wide.

- XDSL, Frame Relay and ATM.

- Internet access and international connectivity.

- 800 Toll free.

- $\quad$ Prepaid Cards.

- $\quad$ Directory Inquiry Telecommunication Services.

Improving the current services and establishing new services reflects excellence in diversity of the Telecommunication services and their quality.

More over, the citizen now can get the Telecommunication service in a standard time which declined the waiting period for the user to buy the needed service.

To enhance the results of the case study, the researcher used the following tow questionnaires to collect related data from the citizens who are care for TCC services.

The techniques and methods of privatization are:

- Methods involving the sale of part of the government's share in the ownership of the organization.

- Methods involving the sale of total government share in the ownership of the organization.

- Methods do not involve the sale.

In Jordan, according to the Privatization Law conducts the total or partial privatization via the following methods:

- IPO for public subscription.

- The contribution of employees through the ownership of all or a certain share of the shares of the economic units put up for privatization.

- Contracts for the operating and capital.

- Management contracts or lease.

- Vocabulary sale of assets owned by the state.

- The sale of shares or quotas in state-owned sector mixed with non-private monopoly.

\section{Data Analysis}

In order to enhance the TCC case study findings, an analysis conducted for the information collected by the questionnaire. Below are the results of this analysis.

Table 1. Sex

\begin{tabular}{llllll}
\hline & & Frequency & Percent & Valid Percent & Cumulative Percent \\
\hline Valid & Male & 31 & 83.8 & 83.8 & 83.8 \\
& Female & 6 & 16.2 & 16.2 & 100.0 \\
& Total & 37 & 100.0 & 100.0 & \\
\hline
\end{tabular}


Table 2. Age

\begin{tabular}{llllll}
\hline & & Frequency & Percent & Valid Percent & Cumulative Percent \\
\hline Valid & 25 years less & 4 & 10.8 & 10.8 & 10.8 \\
& 25-35 years & 8 & 21.6 & 21.6 & 32.4 \\
& 35-45 years & 3 & 8.1 & 8.1 & 40.5 \\
& 45-55 years & 12 & 32.5 & 32.5 & 63.0 \\
& 55 years above & 10 & 27.0 & 27.0 & 100.0 \\
& Total & 37 & 100.0 & 100.0 & \\
\hline
\end{tabular}

Table 3. Testing hypothesis

\begin{tabular}{|c|c|c|c|c|c|}
\hline No. & The statement & Mean & $\begin{array}{l}\text { Standard } \\
\text { Deviation }\end{array}$ & Rank & Level \\
\hline 1. & The citizen can get new telephone in days rather than months. & 3.93 & 0.89 & 1 & High \\
\hline 2. & There are many tellers which means no crowded lines. & 3.68 & 0.91 & 3 & High \\
\hline 3. & $\begin{array}{l}\text { Many services now can be provided in one visit from the } \\
\text { citizen to the organization. }\end{array}$ & 3.65 & 0.95 & 4 & High \\
\hline 4. & $\begin{array}{l}\text { The organization now informs the citizen about his bill } \\
\text { through his telephone. }\end{array}$ & 3.23 & 0.93 & 5 & High \\
\hline 5. & The employees are dealing in ethical ways with the citizens. & 3.82 & 0.90 & 2 & High \\
\hline
\end{tabular}

From table (3) we can note that statement number one obtained the highest mean (3.93) and standard deviation (0.89). Statement Number five obtained the lowest mean of (3.82) with a standard deviation (0.90).

\section{Hypotheses Testing}

In order to test the study hypotheses, Pearson coloration factor was used to find the value ${ }^{\circledR}$ between the independent and dependent variables.

The first hypothesis: There is no relationship between partnership between the public and private sector and the efficiency in providing services in Jordan Telecom.

The data analysis showed that ${ }^{\circledR}$ value for this relationship is 0.552 which means that there is a relationship between the partnership between the public and the private sector and the efficiency in providing services. Also the case of (JTC) supported this relationship.

The second hypothesis: There is no relationship between partnership between the public and private sector and providing the vital services to the citizens in effective ways.

Data analysis showed that ${ }^{\circledR}$ value for this relationship is $(0.661)$ which means a positive relationship between telecommunication services as a vital service and excellence in providing these services.

So we accept the hypothesis in the form of "There is a relationship between partnership between the public and private sector and providing the vital services in an excellent way.

\section{The Study Results}

The study and through the case study and data analysis generated the following results:

1) Partnership between the public and private sectors gives the private sector the opportunity to play his expected role in the development process in the country as a whole.

2) Because of the innovation culture in the private sector, the public services are managed more excellent than the public sector.

3) Partnership between the two sectors promotes customer satisfaction through developing the current services and creating new services.

4) Jordan Telecom services now are more acceptable by the users than before, because of the high quality in these services, and their complementary services.

5) seen the privatization process as a national duty occupies the first priority in the process of economic reform and not a process going strongly automated motivation and by events and results rebounds World Bank and the International Monetary Fund. 
6) Study of the employment situation, which will be indispensable, and labor compensation properly discarded both of the proceeds from the sale of companies in the context of the privatization process or through the Social Solidarity Fund.As well as providing an opportunity for surplus labor to set up small businesses.

7) Reluctance to push chip companies to be put up for sale in the market at one time, but should be gradual as permitted under the capacity of the market to avoid what might happen from the drop in prices as a result of downloading market overstretched.

8) Need advertising budgets of companies to be put up for sale in full, financial indicators and application to Atasr disclosure and transparency as well as providing full information on request of potential investors.

\section{Recommendations}

The study presents the following recommendations especially for (JTC).

1) The necessity of training for the employees to learn them that the citizen is the actual capital for the service sector in any business.

2) The organization have to update its services to be more fit with technological development.

3) The competition in the service sector requires a new culture that makes employees sense the customer needs.

4) Partnership between the two sectors have to be a strategy for the Jordanian government, because of the success of this aspect in may projects.

5) Give workers issues a high degree of importance and continue to work on their involvement in the success of the privatization program in the IPO of the public projects that are filtered

6) Ensure that accompany partnership transparency and clarity in all its stages, as transparency is one of the most important elements of the success of the privatization process because they give greater credibility and thus generate confidence.

7) Careful not to lead the partnership process to the emergence of a new monopoly situations, any move from monopoly to a private monopoly, and requires the selection of privatization method appropriate for such a goal, a style IPO.

8) Ensure that partnership returns used in investment spending and raise the efficiency of human capital and improving human development indicators and the basic structure of society.

\section{References}

AL-Hadid, J. (2008). JC Bank Sponsors the Partnership Forum between the Public and Private Sectors. Zaway $\begin{array}{lllll}\text { Connecting intelligence with intelligence. } & \text { Retrieved }\end{array}$ http://www.zawya.com/story/ZAWYA20080706075923/

AL-Damen, R. (2009). Developing an Excellence Assessment Model for Jordanian Businesses, Dirasat. Administrative Sciences, $36(1) . \quad$ Retrieved from http://research.ju.edu.jo/journals/DirasatAdm/article/viewFile/129/127

AL-Nuaim, A. (2008). Collaboration between the Public and Private Sectors for Urban Development.

AL-Zoubi, A. (2010). Using Entrepreneurship Opportunity in Optimizing Organizational Excellence: A Case Study. Conference University AL-Zaytoonah International Tenth Annual Scientific entitled leading business organizations for period of 20-23-4-2010, in Amman, Jordan.

AL-Zoubi, A. (2011). Creation in the Services \& economical institution. Conference University of Algiers 2 International Scientific fifth on innovation and excellence and their role in providing services to customers for the period from 13-15/3/2011, Algeria.

Ghesquiere, H. (2008). Impact of European Union Association Agreements on Mediterranean Countries. MF Working Paper WP/98/116. Washington, DC.

Gopalatrishnan, P. (2006). Integrated Quality Management. Delhi, India.

Graham, J., \& Herberger, R. (2003). Privatization. Journal of Harvard Business Review, July-August, 160-8.

Gronlund, A. (2000). Managing Electronic Services. UK: Brunal University. http://dx.doi.org/10.1007/978-1-4471-0511-4

Hakim, M. (2011). Current customer satisfaction for the quality of services provided by the Saudi Telecom Company. Journal of King Abdul Aziz, 12(2), 40. 
Hamed, B. (2010). Customer satisfaction level of service delivery in Kuwait Telecom Company. Journal of Social Sciences, 7(3), 61.

Hassan, Mobeen, Alam, Ali, Raza, Muhammad, \& Akram. (2011). A Financial Performance Comparison of Public Vs Private Banks: The Case of Commercial Banking Sector of Pakistan. International Journal of Management and Innovation, 3(2).

Hershock, R. J. (2008, September). Privatization model leading towards investment: the driving force for change. The Planning Forum Network, 6(7), 4.

Hisrich, R., \& Peters, M. (2002). Entrepreneurship. New York: McGraw Hill.

Imamul, H. (2011). Service Quality in Retail Banking - A Comparative Study between Public Sector Banks \& Private Sector Banks. Public Management Review, 12(1), 127-149.

Jordan Times. (2008). Public Sector Partnership a New Concept. Amman, Jordan.

Karmush, M. (2007). Privatization of Telecommunications, the Jordan Example. Jordan E. Deputy Director General of JTC and a Member of the Privatization Committee. Retrieved from http://www.itu.int/ITU-D/arb/WTDC-02/Documents/10-e.pdf

Monica, B. (2010). An integrated frame work for service quality ,customer satisfaction and behavioral responses in Indian banking industry-A comparison of public and private sector banks. Journal of Services Research, 10(1), 157.

Robbins, S., \& Coulter, M. (2005). Management. New Jersey: Prentice Hall.

Smith, R. F. (2008). Government-Private Sector. Partnerships as a Catalyst for Economic Growth and Development.

Süleyman, Yaman, \& Koçak. (2011). The Comparison between Hungary and Turkey. International Journal of Business and Social Science, 2(11).

Sushil. (2000). Flexibility in Management. New Delhi: Vikas Publishing House PVTLTD.

Tanuwidjaja, E. (2006). Analysis on E-Government. National University of Singapore.

Tortajada, C. (2002). Workshop on Public- Private Partnership in the Water Sector: The Case of the Middle East and North Africa Region. Egypt, Cairo. Retrieved from http://www.thirdworldcentre.org/cairo.PDF

Xie, B., Davidson, W. N. III, \& DaDalt, P. J. (2003). Privatization strategy success of the State and Corporate Governance: The Roles of the Board and the Audit Committee. Journal of Corporate Finance, 9, 295-316. http://dx.doi.org/10.1016/S0929-1199(02)00006-8

\section{Appendix: Citizens Questionnaire}

\section{Part One:}

This part includes the demographic characteristics of the sample, for that you are requested to put $(\sqrt{ })$ in the proper place.

\begin{tabular}{|c|c|c|c|}
\hline Gender: & $\square$ Female & $\square$ Male & \\
\hline Age: & $\square$ Less than 25 years & $\square$ 25-35 years & $\square 35$ - less than 45 \\
\hline & $\square 45$ - less than 55 years & $\square$ 55years and over & \\
\hline
\end{tabular}

Part Two:

\begin{tabular}{|c|c|c|c|c|c|c|}
\hline No. & The Statement & Strongly Agree & Agree & Neutral & Disagree & Strongly Disagree \\
\hline 1. & $\begin{array}{l}\text { The citizen now can get a new telephone } \\
\text { line and number in the same day rather } \\
\text { than waiting months. }\end{array}$ & & & & & \\
\hline 2. & $\begin{array}{l}\text { Now there are many tellers, so the citizen } \\
\text { can pay his bill in standard time. }\end{array}$ & & & & & \\
\hline 3. & $\begin{array}{l}\text { Many marketing services now can be } \\
\text { provided for the citizen in one visit to the } \\
\text { organization. }\end{array}$ & & & & & \\
\hline 4. & $\begin{array}{l}\text { The organization now informs the citizen } \\
\text { about his bill through his telephone. }\end{array}$ & & & & & \\
\hline
\end{tabular}


5. The employees in the organization are dealing in ethical ways with the citizen.

\section{Copyrights}

Copyright for this article is retained by the author(s), with first publication rights granted to the journal.

This is an open-access article distributed under the terms and conditions of the Creative Commons Attribution license (http://creativecommons.org/licenses/by/3.0/). 